During this period, Wilson collaborated with Sir Charles Martin and, more partieularly, with Prof. J. P. Hill in research work, as a result of which many papers of fundamental importance were published on the structure and development of monotremes and marsupials. The late Sir Grafton Elliot Smith was one of his earliest pupils, and there is no doubt that Wilson's guidance and stimulating influence must have counted for much in laying the foundations for his later brilliant work.

In 1920, Wilson accepted the chair of anatomy at Cambridge. Although a comparative stranger, his outstanding abilities were quickly recognized, and he gained the respect and affection of all who worked with him in the University, and of the society of St. John's College, where he was elected to a fellowship in the same year. His work for the Cambridge Anatomy School is well known. During his fourteen years tenure of office, he enlarged and reorganized the course in anatomy for Part I of the Natural Sciences Tripos, created an excellent departmental library to which he gave a great part of his private collection of books and papers, and attracted each year a small number of students to take anatomy in Part II of the Tripos.

Wilson's scientific work was always characterized by meticulous care and thoroughness, and his papers were models in their exactness of expression and lucidity. The value of his contributions to natural science was recognized by his election into the fellowship of the Royal Society in 1909. In his later years, while at Cambridge, he spent a considerable part of his time in perfecting a technique by means of which a series of sections of large embryos could be exploited to the greatest advantage; the enthusiasm which he showed in the development of the method, and in the demonstration of his specimens to those immediately around him, was wholly characteristic; it is a great loss to embryology that but few of the many critical and original observations which he made as a result were published.

After his resignation from the chair at Cambridge in 1934, he continued to lead a full and active life; that his judgment was held in the highest esteem to the end is evidenced by the fact that this year, at the age of eighty-four, he was asked to continue his Carnegie Reports for a further year. He was the first overseas member of the Anatomical Society of Great Britain and Ireland, and he acted as its president during the years 1922-24.

This record of scientific and administrative achievement alone would place Wilson high in the ranks of great medical teachers, but his greatness and influence were more profound and far-reaching than can be indicated by a mere statement of facts. His personal example and his friendship had a marked and lasting effect on generations of students; medical men who were trained at Sydney during Wilson's time still say, when his name is mentioned, "Oh, you mean Jummy", and go on to speak of him with a spontaneous fervour delightful to hear. $\mathrm{He}_{\Theta}$ had great charm of manner and a natural power of inspiring those around him; he was actuated by the highest ideals, the sincerity of which was recognized and appreciated by the members of his staff and by his students. As with his scientific work, thoroughness and enthusiasm permeated every aspect of his teaching; he gave without stint of his time, knowledge and experience, and no one could fail to be the better man for having met and worked with him.

H. L. H. H. GREeN.

\section{Prof. W. H. Fraenkel}

THE death occurred on July 14, 1945, of Prof. Walter Fraenkel, who was living at Perth Amboy in the United States. $\mathrm{He}_{e}$ had been expelled from Germany early in 1939 by the Hitler Government and, after spending nearly a year at the University of Cambridge, as guest of the Metallurgical Laboratories, emigrated with his family to the United. States.

Fraenkel's work covered problems of the age hardening of aluminium alloys, diffusion, segregation and crystallization and chemical reaction between metal and slag; the latter in close co-operation with R. Lorentz. Fraenkel held a professorship in Frankfurt-am-Main and there most of his research work was done, with the help of a small band of enthusiastic and devoted pupils.

Two short periods in industrial research during the First World War and in the thirties gave him an opportunity of learning about industrial problems and the industrial way of technical development.

Prof. Fraenkel was a physical chemist (trained under Bredig and Lorentz) and his approach to problems of metallurgy was always from this angle, as was the method of his teacher in this field, Tammann. He even introduced the kinetics of reaction into metallurgy in his work on the age hardening of duralumin, a problem which fascinated him during almost the whole of his research work. His studies on this subject were among the earliest scientific work done on this important theme.

I happened to be the first student who chose a subject in Prof. Fraenkel's own line of research for a thesis. The work was carried on in closest collaboration with him. $\mathrm{He}_{\mathrm{k}} \mathrm{knew}$ and watched every step and, in long and almost daily discussions, an intimate view of the man and his work was obtained, and also no small inspiration from his general attitude towards science and scientific work. His rigorous criticism of any results, be it his own or other workers, without regard to name and reputation, his modesty and his complete devotion to the cause of truth and science, were among his outstanding characteristics.

In spite of the almost pessimistic severity of his general outlook and many personal disappointments, Prof. Fraenkel possessed a keen sense of humour and a caustic wit that spared nobody, least of all himself. All his pupils and his colleagues will honour his memory as that of a man of high principles, a most capable and careful man of science and teacher and a kind and reliable friend.

E. SCHEUER.

\section{Dr. William Cramer}

Wirliam Cramer was borm in the Rhineland on June 2, 1878. After taking his Ph.D. at the University of Berlin in 1901, he worked in its department of pharmacology. There he met E. F. Bashford, and their friendship resulted in his joining the staff of the Imperial Cancer Research Fund in 1903. Thus he came to collaborate with Bashford and Murray in that pioneer work which contributed so much to our knowledge of the growth of cancer under experimental conditions.

In 1905, Cramer went to Edinburgh as lecturer in chemical physiology in Sharpey-Schafer's Department, and took the degree of D.Sc. three years later. He published "Directions for a Practical Course in Chemical Physiology" in 1912, which ran to four editions. His position as a university teacher became somewhat difficult on the outbreak of the First 